\title{
RAE ARTICLES
}

\section{INCLUSION AND DIVERSITY IN MANAGEMENT: A MANIFESTA FOR THE FUTURE-NOW}

\author{
Inclusão e diversidade na Administração: Manifesta para o futuro-presente \\ Inclusión y diversidad en la Administración: Manifiesta para el futuro-presente
}

\author{
Juliana Cristina Teixeira1 ${ }^{1}$ julianacteixeira@yahoo.com.br | ORCID: 0000-0001-5186-3234 \\ Josiane Silva de Oliveira2,3 | oliveira.josianesilva@gmail.com | ORCID: 0000-0002-7085-8921 \\ Ana Diniz | anaprd@insper.edu.br | ORCID: 0000-0002-9187-3696 \\ Mariana Mazzini Marcondes5 | mariana.mazzini.m@gmail.com | ORCID: 0000-0003-0701-6630
}

\footnotetext{
${ }^{1}$ Universidade Federal do Espírito Santo, Departamento e Programa de Pós-Graduação em Administração, Núcleo de Estudos Afro-Brasileiros, Vitória, ES, Brazil

${ }^{2}$ Universidade Estadual de Maringá, Departamento e Programa de Pós-graduação em Administração, Núcleo de Estudos Interdisciplinares Afrobrasileiros, Maringá, PR, Brazil

Universidade Federal de Goiás, Programa de Pós-graduação em Administração, Goiânia, GO, Brazil

4 Insper Instituto de Ensino e Pesquisa, São Paulo, SP, Brazil

${ }^{5}$ Universidade Federal do Rio Grande do Norte, Departamento de Administração Pública e Gestão Social do Centro de Ciências Sociais Aplicadas, Natal, Rio Grande do Norte, Brazil
}

\begin{abstract}
In marking the anniversary of RAE-Revista de Administração de Empresas, the purpose of this article, which can be interpreted as a manifesta, is to discuss the role of academic journals in Management with regard to inclusion and diversity. We understand that when we talk about the role of journals in processes for repairing historical inequalities we are also talking about reconnecting with criticisms of the concept and practice of diversity that are found in the field of Management, and it is precisely with this debate that we begin to build our argument right after the introduction. Based on theoretical references that are systematized by the practices and knowledge of social movements (intersectionality, mainstreaming and "decoloniality"), we present our manifesta for an agenda of transformations for practices relating to diversity in the field.
\end{abstract}

KEYWORDS | Diversity, inequality, intersectionality, mainstreaming, decoloniality.

\section{RESUMO}

No marco temporal de aniversário da RAE-Revista de Administração de Empresas, o objetivo deste artigo, que pode ser interpretado como uma manifesta, é discutir o papel das revistas acadêmicas em Administração para a inclusão e a diversidade. Entendemos que nos manifestarmos sobre o papel das revistas em processos de reparação histórica de desigualdades é também sobre nos reconectar com a crítica ao conceito e à prática da diversidade presentes no campo da Administração, e é justamente por esse debate que iniciamos a construção do nosso argumento, logo após a introdução. Ancorando-nos em referenciais teóricos sistematizados a partir das práticas e dos conhecimentos dos movimentos sociais (interseccionalidade, transversalidade e decolonialidade), apresentamos nossa manifesta por uma agenda de transformações para as práticas sobre diversidade no campo.

PALAVRAS-CHAVE / Diversidade, desigualdades, interseccionalidade, transversalidade, decolonialidade.

\section{RESUMEN}

En el marco temporal del aniversario de la RAE-Revista de Administração de Empresas, el objetivo de este artículo, que puede interpretarse como un manifiesta, es discutir el papel de las revistas académicas de Administración para la inclusión y la diversidad. Entendemos que manifestarnos sobre el papel de las revistas en procesos de reparación histórica de desigualdades es también reconectarnos con la crítica al concepto y a la práctica de la diversidad presente en el campo de la Administración, y es precisamente a través de ese debate que comenzamos la construcción de nuestro argumento, inmediatamente después de la introducción. Respaldándonos en marcos referenciales teóricos sistematizados a partir de las prácticas y de los conocimientos de los movimientos sociales (interseccionalidad, transversalidad y decolonialidad), presentamos nuestro manifiesta por una agenda de transformaciones para las prácticas sobre diversidad en el campo.

PALABRAS CLAVE / Diversidad, desigualdades, interseccionalidad, transversalidad, decolonialidad. 


\section{INTRODUCTION}

Resorting to the use of Ebonics [Pretuguês ${ }^{1}$ - Gonzalez, 1984], "how about y'all start this text with a reflection exercise?" Let us look at a hypothetical situation in which we consider the barriers to promoting inclusion and diversity in Management. One of the stages in this process involves writing, publishing and fostering the development of works on the topic in order to construct an agenda of debates in the field. Imagine, then, that you are a researcher in Organization Studies and you received an invitation to compose a group of scholars to guestedit a special issue on diversity and inclusion in a journal that tops the Qualis Capes Academic Journals ranking:

1. Who would you invite to be in your group?

2. Imagine this group needs to comprise $50 \%$ men and $50 \%$ women. Would your initial composition serve? How would you adjust it? How would you tell those who would need to leave the group? How would you invite new people in order to achieve this distribution requirement?

3. The group also needs to comprise $50 \%$ non-white people and $50 \%$ white. Was that what the group was originally like? If not, would it be easy to adjust it?

4. In addition to the above requirements, the group needs to be equally divided between heterosexuals and non-heterosexuals. What would you do?

5. What if, in addition to what has been said, the group needed to be comprised also of cisgender people, transvestites, and transgender and transsexual people? Would you be able to put together a group like this in your research area?

6. What if you also needed to have at least one representative from indigenous groups, or from former slave communities? What now?

7. Finally, what if it were necessary to include people from regions other than the Southeast or South of Brazil? Was your group like hat?

8. The exercise has not finished yet; there is a little more to do. Go back over this whole exercise and imagine that this group has to be comprised of male and female researchers from other areas in Management, such as Finance, Logistics, or others; what would it be like then?

“Tell us, did y'all manage to compose the groups mentally?" We imagine not, because even we, the writers of this article, who have political and academic backgrounds in these topics, find it difficult to diversify our group. We are four heterosexual cisgender women, two black and two white, all born in the Southeast and South of Brazil, although two of us work in institutions outside this area.

Our careers so far include the joint coordination of the topic of inequalities and differences in the Organization Studies division of National Association of Postgraduation and Research in Administration (Associação Nacional de

[1] Pretuguês is the name suggested by Lélia Gonzalez (1984) for the Portuguese that is spoken in Brazil, which has been heavily influenced by the way the black people who came to Brazil to be enslaved in the forced diaspora from the African continent. This influence explains the ways of speaking that transform você (you) into cê (y'all), that drop the final "R" from the infinitive form of verbs (escrevê, fazê instead of escrever, fazer), and who exchange e L sound for R (Creusa instead of Cleusa)). Lélia points out that these marks were ignored by racism, when they incorporated an idea that black people are intellectually inferior, which is why they are disconnected from the cultured norms of the Portuguese language. 
Pós-Graduação e Pesquisa em Administração [ANPAD]), and academic and professional activities in this area and/ or in the field of Public Administration. Our areas are marked by epistemological, theoretical and methodological plurality. This plurality is lost, however, when the subject is the adequate representativity of the diversity that goes to make up our country in terms of the faculty members and students in this field.

On this anniversary of RAE-Revista de Administração de Empresas, the initial objective of this text, which can also be understood to be a manifesta, was to discuss the role of academic journals in Management in relation to inclusion and diversity. It would be like thinking about an agenda for the future. The structure of our argument, however, goes beyond the sphere of academic journals, although it also refers to them.

We propose expanding the discussion to incorporate the field of Management. This proposal is based on: (1) our experiences in articulating debate on topics in the field, which also includes political and academic activities behind the scenes of its institutionalized practices; (2) a theoretical contribution that is connected with the educational experiences of social movements: intersectionality, decoloniality and mainstreaming; and (3) the intrinsic character of academic debate with its more structural social transformation.

In this sense, we believe that expressing ourselves on the role of journals in processes for repairing historical inequalities is also about reconnecting with the main critiques of the concept and practice of diversity in the field; it is with this debate that we begin to construct our argument, right after this introduction. We then discuss the theoretical foundation of our agenda, while in the fourth part we present our manifesta for a transformation agenda in Management.

In practical terms we believe that inviting a black person and a woman onto a panel on diversity, for example, is not practicing diversity. We operate in contexts in which superficial actions have helped de-politicize the agenda. When we move from this uncritical view to another that is critical and transformative with regard to inequalities, we recognize that we need to act in a more profound way, at the very roots of the field. We argue that superficial actions are merely steps, because the insurgencies in our area depend on breaking with the pattern of episodic moments for structural transformations towards diversity. Our argument develops an understanding of the implications of this debate for the different areas, and connecting with the field of Management as a whole.

\section{DIVERSITY IN MANAGEMENT}

The debate about diversity in Management has gained in strength in the United States since the 1990s (Cox \& Blake, 1991; Fleury, 2000). Better structured initiatives for dealing with the issue, however, date back to the 1960s, when the first affirmative public policies were developed in the country in response to demands from the Civil Rights Movement (Moehlecke, 2002; Pate, 2000). The legal foundations of these initiatives refer, in turn, to the broader international context, as recommended in United Nations' treaties and conventions, as well as in national legislation (Hodges-Aeberhard, 1999), such as in Brazil (Bandeira, 2005; Jaccoud \& Beghin, 2002).

Since 1960, affirmative action has spread throughout the world, but this has not happened without dispute (Moehlecke, 2002; Pate, 2000). The questions raised emphasize that this type of policy is a form of "reverse discrimination", a means of devaluing the achievements of the beneficiary groups or, even, of reinforcing a kind of "tribalism" between groups (Piovesan, 2008; Scott, 2005). Such criticisms formed the basis of a wave of lawsuits against affirmative policies in the US in the 1990s, which were brought mainly by workers and students who felt they had been wronged in selection and professional advancement processes (Hodges-Aeberhard, 1999). 
It is in this context that a managerial alternative emerges for dealing with diversity at work (Alves \& GaleãoSilva, 2004). Diversity management is a set of practices that aim both to increase the participation of excluded groups in organizations and to add value to companies (Fleury, 2000). In this process, diversity is often understood as a mix of people with different individual and group attributes (Alves \& Galeão-Silva, 2004). This would include not only differences that have been historically dealt with as sources of inequality, such as gender, sexuality, race, ethnicity and class, but multiple differences between people (Hanashiro \& Carvalho, 2005). According to this perspective, the identities and skills that result from this plurality must be managed as strategic resources for increasing organizational performance (Thomas, 1990).

The defense of diversity management is based on two main points (Alves \& Galeão-Silva, 2004). First, this proposal would allow for the construction of fairer programs that are based on "meritocracy". Alignment with the business logic would also make these initiatives more "organic" and effective in creating an organizational environment that is favorable to difference (Hanashiro \& Carvalho, 2005). Second, diversity management would make it possible to mitigate the disadvantages and expand the advantages of different teams (Conceição \& Spink, 2013; Prügl, 2011), which becomes even more crucial in a globalized and competitive context in which homogeneity between male and female workers would no longer be an option for companies. There came a turning point, therefore, in discourses about diversity and management: it was no longer a question of social justice, but of business survival (Thomas, 1990).

Diversity management was incorporated in Brazil in the 1990s, brought in mainly by the subsidiaries of North American multinationals (Fleury, 2000; Hanashiro \& Carvalho, 2005), but the proposal never took off in the country (Conceição \& Spink, 2013; Santos, Rodrigues, Dutra, \& Costa, 2008). A survey by the Ethos Institute (2016) shows that in the 500 largest companies in Brazil only $28 \%$ adopt initiatives for encouraging the participation of women, $12 \%$ for black people and $9 \%$ for those over 45 years old, and most of these initiatives are one-off actions. Even programs for people with disabilities are not widespread, despite the existing legal provisions for encouraging the insertion of this group. Studies (e.g., by Diniz, Carrieri, Gandra, \& Bicalho, 2013; Saraiva \& Irigaray, 2009) have also pointed to the ineffectiveness of the programs that have been implemented, since they do not include an ethical-moral reflection that supports the practices that are developed, there is a lack of managerial commitment and prejudice is deep-rooted in organizational dynamics.

Barriers are also observed in the advancement of research on the topic. Maria Tereza Leme Fleury's (2000) article in $R A E$, which initiated debate about diversity in the field, was followed by a substantial increase in publications, many of them debating the limits of the practice and the possibilities for improvement. These works have been expanded upon by studies that are not always supported by the theoretical key of diversity, but that offer reflections on, among other things, the generational and regional inequalities in gender, sexuality, race and ethnicity, and those faced by people with disabilities. A similar movement in the area can be seen in congresses, such as EnANPAD, which include topics dedicated to diversity and differences, and meetings, such as EnEO, EnAPG and EnGPR. But this debate, which is fundamental for Management, follows a resistance front that is marginalized by the hegemony of the field and "ghettoized" in specific areas, such as Organization Studies and Public Management.

Limits can also be observed when it comes to promoting a more forceful reflection-action for transforming Management schools and their academic environment. Teacher and student bodies are mostly male, white and privileged. Analysis of the 2019-2020 database of the Coordination for the Improvement of Higher Education Personnel [Coordenação de Aperfeiçoamento de Pessoal de Nível Superior] (CAPES, 2021) shows that only $33 \%$ of 
the teachers in graduate programs in the area are women. Female participation is even lower in programs rated Level 5 and 6 [very good/excellent]. A regional disparity is also evident, with $45 \%$ of the programs concentrated in the Southeast and $25 \%$ in the South. Data that might allow us to reflect on the racial, ethnic and economic disparities and those related to sexual and gender identities are not even collected, revealing how far away we are from having a coherent policy that favors the inclusion of black, poor, trans and non-heterosexual people in graduate program faculty in Brazil.

A look at the student body, however, indicates possibilities for change. Women make up $46 \%$ of the students in graduate programs in Public and Business Management, Accounting and Tourism. There is a greater female participation on academic courses; $48 \%$ compared with $43 \%$ of female students studying for a professional Master's or PhD. As with teachers, there are fewer female students on Level 5 and 6 programs and in private university programs. The largest female participation is headed by young women who already exceed $50 \%$ of all students up to 29 years old (CAPES, 2021). Women also account for $54.9 \%$ of the students in undergraduate courses in Business, Management and Law. Black people, however, are still underrepresented in higher education courses, generally, despite the relevant progress made as a result of quota policies (Semesp, 2020).

The limits for the advancement of diversity refer to the way in which the debate on differences and inequalities has been hegemonically incorporated into Management. In a work on black executives, Jaime (2016) discusses how diversity management was adopted as a language for mediating the conflict between organizations, government agents and civil society. This "translation", however, led to a depoliticization of the historical agendas of social movements. As Alves and Galeão-Silva (2004) show, managerial proposals shift the issue of differences from a political, uncontrollable and corporate conflict to an apolitical and functional variable, thereby submitting the demand for inclusion to a market logic, a logic that is not only male, but white and colonial (Gonzalez, 1984).

In the following section, we suggest an alternative approach that seeks to re-politicize and increase reflectionaction for achieving diversity and inclusion in the field.

\section{INTERSECTIONALITY, DECOLONIALITY AND MAINSTREAMING}

In order to re-politicize the theories and practices of Management in relation to inclusion and diversity, we need to move beyond individual solutions in order to get to the roots of this problem, and this requires understanding the institutional and structural dimensions that shape the field as it is permeated by the historical and political relations that provide social reality as a whole with its materiality (Ramos, 1981). In order to do so we can draw a parallel with theoretical-political discussions about racism.

In the words of Joel Rufino dos Santos (1999), racism is not a set of episodic phenomena for countering our understanding of it as a “minority” problem" (p. 120). Racism is an oppression system based on a notion of race as an ideology (Munanga, 2015) that acts as a psychic organizer of individuals and groups (Santos, 1983). Based on an ideology that is interspersed with the effects of capitalism and sexism (Gonzalez, 1984), racism promotes ways of structuring society at its various levels, including at the institutional level.

In the formation of modern organizations, however, mimicry promoted the appearance that "black is race", remembering Santos's (1999) criticism of how black people are seen in Brazil. The author points out that "black" is a social place that is maintained by an unequal and excluding structure (Santos, 1999), which must also be 
understood as relational in the place of whiteness, which reverberates as a power standard in these organizations (Gouvêa \& Oliveira, 2020).

In a parallel with the theory of organizations, Peci (2006) draws attention to the way in which organizational mimicry is overestimated as a phenomenon for understanding the formation and regulation of institutions in institutional theories, which are classic in the field of Management. Returning to the racial discussion, racism also tends to be treated as just individual or group mimicry, and not as something structural that is sustained by the historical power relations in our society (Almeida, 2018).

Based on these reflections, we understand that the construction of a field that is committed to tackling inequalities and promoting inclusion and diversity involves forging instruments that allow us to operate within this structural complexity. In this manifesta, we examine the knowledge and transformative practices that have been developed by social movements, especially the feminist (and) black movements, when proposing a transformative agenda for Management. To do so we are supported by three concepts (which are also three practices) for setting out a path of reflection-action with regard to concrete proposals for the field. They are: intersectionality, decoloniality and mainstreaming.

Intersectionality was systematized by Kimberlé Crenshaw in 1989 (Teixeira, 2020). The history of intersectionality, however, permeates the actions of black women for politicizing race, gender and class relations in an articulated way. During women's rights conventions in the United States in 1851, Sojourner Truth, an enslaved black woman, asked: "Has anybody ever helped me get into a carriage ... or jump over muddy puddles ... And am I not a woman?" (Truth, 1851). In asking this question, she pointed out that the construction of a universal female was, in fact, a generalization of the experiences of middle- and upper-class white women.

The contributions of black American intellectuals, such as Angela Davis (2016), Audre Lorde (1984) and bell hooks (2000), were fundamental to the development of intersectional theories and practices over time. But it is also essential to highlight the contributions of the Global South, such as those developed by Brazilians, Lélia Gonzalez (1984), Beatriz Nascimento (1990) and Sueli Carneiro (2003), and even reflect on the fact that these authors are not included when the concept is systematized.

Based on Crenshaw (2002), we understand intersectionality to be the linking of the axes of power and discrimination that structurally produce oppression. This is the case with social race, ethnicity, gender, sexuality and class relations. We need, therefore, to think and act in a connected and integrated way if we wish to produce equality and inclusion with respect to diversity.

Decoloniality, in its turn, can be understood as a project that, on the one hand, systematizes a criticism of coloniality (Quijano, 2005) and, on the other, presents an alternative to it (Abdalla \& Faria, 2017; Alcadipani \& Rosa, 2010; Amaral \& Naves, 2020; Rezende, Mafra, \& Pereira, 2018; Silva, André, Wanderley, \& Bauer, 2020).

Coloniality refers to the project of colonial modernity that separates and hierarchizes races, peoples, genders, sexualities, cultures, languages and knowledge, as a way of establishing and legitimizing Eurocentric hegemony. It goes beyond the historical process by which European countries colonized America, Africa and Asia, and which integrated (and structured) the contemporary capitalist way of production. Its effects are not limited to the geopolitical organization of the economy by the international division of labor (center/periphery), but encompass the construction of hegemonic forms of rationality and epistemes, including language (like the use of English as a universal language). It is a monoculture of knowledge (Santos, Araújo, \& Baumgarten, 2016). Decoloniality, on the other hand, is a theoretical and practical proposal for politically repositioning marginalized subjects and peoples as the origin and source of knowledge and practices (Lugones, 2014). 
Constructing mediation between decoloniality and intersectionality offers us a solid basis for reflection. Decolonizing is, to a large extent, recognizing the intersection that relates to forms of inequality, and building paths so that those subjects and communities that live on the margins become the center of an emancipatory project, while intersectionality becomes more powerful as it decolonizes.

Finally, we turn to gender mainstreaming, which is translated into Portuguese as transversalidade de gênero (Farah, 2004; Papa, 2012; Reinach, 2013). Mainstreaming refers to the efforts of feminist movements to forge strategies for ensuring that public action is committed to gender equality. This strategy was disseminated following the IV World Conference on Women, which was held in Beijing, in 1995, and supports the development of public policies in various countries (Guzmán, 2001; Walby, 2005). In Brazil, it was the basis of initiatives for institutionalizing policies for women (Bandeira, 2005; Marcondes, 2019; Papa, 2012), and for equality in terms of race, youth and human rights (Marcondes, Sandim, \& Diniz, 2018; Reinach, 2013), especially when PT [Workers Party] was in power in the federal government.

Based on feminist literature on the subject (Bandeira, 2005; Farah, 2004; Marcondes, 2019), we understand mainstreaming to be a process that seeks to reorient reflection-action through the introduction of perspectives (of gender, race, ethnicity, etc.) that commit it to promoting equality and the inclusion of historically discriminatedagainst subjects. This is an essentially conflicting and contradictory dynamic, and its results are permeated by nuances and even discontinuities.

Mainstreaming involves a dispute with regard to the ideologies and discourses that structure the problems and the action alternatives for responding to them. Reorientation from the perspective of gender equality, for example, presupposes recognizing that, historically, thought and action were committed to producing and legitimizing gender inequality. Mainstreaming should also encompass making material and institutional conditions feasible so that it can be managed effectively. This is the case with the creation of coordinating bodies and the development of plans and indicators, among other instruments.

Mainstreaming, therefore, seeks to reorient reflection-action in a different direction from the one it has historically followed, which will bring marginalized perspectives to the center. In this process mainstreaming can be based on intersectionality and decoloniality in order to boost its effects, and although it has been used mainly at the state level, it offers instruments for disputing and transforming other spaces, such as the Management field itself.

Based on these references, we introduce the following proposals.

\section{FOR A TRANSFORMATIVE AGENDA}

In order to expand the topics and the participation of groups that have been historically confined to the margins of the field, we need to change the logic of a field that turns these groups into objects in the world and not subjects. This transformation agenda must consider several fronts.

Initially, we need to consider that who creates the idea of what we know about diversity is the one who occupies the place of the norm. From an intersectional perspective, therefore, those elements that we were told are the norm and that result from the way in which life, in terms of gender, sexuality, race, ethnicity, class and disability, for example, is socio-economically produced and organized, need to be denaturalized. This should be open for debate to the extent that even the constitution logic of institutions can be questioned and shown 
as being singular not universal points of view. Whereas Fanon (2020) tells us white people created black people from their fantasies, Said (2007) alerts us to this same understanding in the relationship between the West and the East, while Lugones (2014) does so in relation to the debates about gender and colonialism. Therefore, what has been called diversity needs to stop reaffirming the norm, and start being constituted by its own processes.

This implies a second front for this agenda, which has to do with the composition rules of the institutions that articulate these debates, which can be thought of in a critical and purposeful way, and from an intersectional perspective. This is important because, without the material conditions necessary for this diversity agenda to take effect, it will once again become a proposal for a future that will never arrive, that remains on the sidelines. Here, we turn to the question of resource distribution, including financial resources, the occupation of spaces on the editorial bodies of journals and class associations, and the recognition of technologies and management processes that break with the logic of preserving processes that are, whether explicitly or not, excluding.

One of the ways in which these technologies are manifested is through language (Gonzalez, 1984). The international integration of our work processes is important, but this does not necessarily mean the hegemony of the English language. For instance, the Spanish language continues to be neglected by the Brazilian editorial management. This questioning also applies to the adoption of English as the official language for teaching classes in the Management area. This use of English in Brazil, a part of Latin America and the Global South, points to one of the mechanisms that show for whom these spaces are destined and how they are reproduced, which prevents diversity. Another example of this mechanism is the business journals silence about the promotion of accessibility of studies in the Brazilian sign language to nationalize the research in the field. Adopting a research agenda that talks about diversity while suppressing this diversity in daily life turns these discussions into an object and not a project to be carried out in a scientific area.

We need to consider that it is not only the presence of trans and black people, women, and those with disabilities or who come from developing countries, for example, that will ensure that an institution becomes effectively engaged with this agenda. The issue is rather the effectiveness of another operating logic for overcoming inequalities, one that permeates the actual occupation of these spaces (or suppression of them) by these social groups. This occupation cannot be treated superficially as the co-option of difference, which is observed both in the dynamics of internal survival in the scientific field and in its internationalization agendas. In this sense, we need to discuss to what extent the vision of internationalization can be configured as the co-option of difference and "hegemonization" by the Global North. We can (and should) ask ourselves: Why does internationalization not come from the Global South, or via other languages, such as Spanish?

The third front proposed for a diversity agenda concerns research topics. The theme of inequalities and diversities is mainstream and a constituent part of the field of Management. There are financial implications, but also implications for the formation of supply and logistics chains, for our modes of production and consumption, and for the information technologies that structure and organize all these debates and that may present us with other reflections and proposals for intervention over and above public policies and people management or organization policies. In order to constitute a mainstreaming process, which is understood as a reorientation of the course of Management theories and practices in favor of equality and inclusion, material and institutional conditions need to be created so that this dispute can be repositioned, and shift from the margin to the center.

In this same sense, it is important to create mechanisms for managing this mainstreaming, such as action plans that have goals and indicators, and bodies that allow this process to be managed, and that can be adopted in a wide variety of academic organizations (universities, research associations, editorial boards) and involve social participation.

Going further, it is necessary to move forward with an agenda of topics that includes a debate on deconstructing silences, and also encompasses "who invented" what is called diversity. In discussions about gender, different 
masculinities and their intersections with race, class, sexuality, nationality or regionality need to be understood from an intersectional perspective. Not all masculinities are hegemonic, for example. Neither are all heterosexualities hegemonic; there are transvestites, and transgender and transsexual people who are heterosexual. What has been called diversity is also related to a specific understanding of male hegemony in the area, which is represented by middle class, heterosexual white cis men, who live in the Southeast and South of Brazil.

On the other hand, despite the fact that Brazil is one of the world leaders in the murder of transvestites, and transgender and transsexual people, there is little discussion about how management practices reproduce this logic in the country, or even the possibility that these practices might produce other realities in the daily lives of this group of people. Paniza (2020) argues that one possibility for the area is also to question "the adoption of acronyms (such as LGBT) as being universally representative and unified concepts" ( $p .13)$. The very idea of a joint construction of agendas with social movements would include an agenda that is committed to reversing a situation in which gays become the subjects of research in the area, but those who represent the other letters of the acronym are silenced.

In terms of race relations, although debates on whiteness have theoretically advanced in the fields of Sociology, History, Anthropology or Psychology, there is still a long way to go in Management. If, largely as a result of provocations from the field of black feminism, topics linked to black populations have made it possible to make progress with these debates, discussions about indigenous people and other racial groups, such as conflicts in Arab and Asian territories, are still rarely presented in our field. This scenario suggests that there are opportunities for reconsidering the limits of the movements of decolonial proposals in the field.

There is little discussion, for example, of the effects of aging in administration (Cepellos, Silva, \& Tonelli, 2019), or what it is like to grow old in a context in which time is considered to be a variable that must be controlled. Finally, many of the studies into diversity occur in the urban context. Male and female rural workers, organizational processes in and of the countryside, and the different rural contexts are still little studied for understanding their diversity. Likewise, our relationships with nature, where we find ourselves in debates about the Anthropocene, contribute and should be discussed in all their breadth in the Management area.

\section{NOTE}

We have kept the full forenames of the authors to clearly indicate female production.

\section{REFERENCES}

Abdalla, Marcio M., \& Faria, Alex. (2017). Em defesa da opção decolonial em administração/gestão. Cadernos EBAPE.BR, 15(4), 914-929. doi: 10.1590/1679-395155249

Alcadipani, Rafael, \& Rosa, Alexandre R. (2010). O pesquisador como o outro: Uma leitura pós-colonial do "Borat" brasileiro. RAE-Revista de Administração de Empresas, 50(4), 371-382. doi: $10.1590 /$ So034-75902010000400003

Almeida, Silvio. (2018). Racismo estrutural. Belo Horizonte, MG: Letramento.
Alves, Mário A., \& Galeão-Silva, Luiz Guilherme. (2004). A crítica da gestão da diversidade nas organizações. RAE-Revista de Administração de Empresas, 44(3), 20-29. doi: 10.1590/ So034-75902004000300003

Amaral, Isabela G., \& Naves, Flávia. (2020). O enfrentamento das opressões de gênero numa universidade pública: 0 papel dos coletivos na ótica do feminismo decolonial. Revista Brasileira de Estudos Organizacionais, 7(1), 151-184. doi: 10.21583/2447-4851.rbeo.2020.v7n1.305 
Bandeira, Lourdes M. (2005). Fortalecimento da Secretaria Especial de Políticas para as Mulheres: Avançar na transversalidade da perspectiva de gênero nas políticas públicas. Brasília, DF: Cepal; SPM.

Carneiro, Sueli. (2003). Mulheres em movimento. Estudos Avançados, 17(49), 117-133. doi: 10.1590/S0103-40142003000300008

Cepellos, Vanessa M., Silva, Gabriela T., \& Tonelli, Maria José. (2019). Envelhecimento: Múltiplas idades na construção da idade profissional. Organizações \& Sociedade, 26(89), 269290. doi: 10.1590/1984-9260894

Conceição, Eliane B. da, \& Spink, Peter K. (2013). Which foot first: Diversity management and affirmative action in Brazilian business. Management International, 17, 25-36. doi: 10.7202/1015809ar

Coordenação de Aperfeiçoamento de Pessoal de Nível Superior. (2021). Conjunto de dados abertos da CAPES. Planilhas em Excel. Retrieved from https://dadosabertos.capes.gov.br/ dataset

Cox, Taylor H., \& Blake, Stacy. (1991). Managing cultural diversity: Implications for competitiveness organizational. The Executive (Academy of Management), 5(3), 45-56. doi: 10.5465/ame.1991.4274465

Crenshaw, Kimberlé. (2002). Documento para o encontro de especialistas em aspectos da discriminação racial relativos ao gênero. Revista Estudos Feministas, 10(1), 171-188. doi: 10.1590/s0104-026×2002000100011

Davis, Angela. (2016). Mulheres, raça e classe. São Paulo, SP: Boitempo.

Diniz, Ana Paula R., Carrieri, Alexandre de P., Gandra, Gislaine, \& Bicalho, Renata de A. (2013). Políticas de diversidade nas organizações: As relações de trabalho comentadas por trabalhadores homossexuais. Revista Economia \& Gestão, 13(31), 93-114. doi: 10.5752/P.1984-6606.2013V13n31p93

Fanon, Frantz. (2020). Pele negra, máscaras brancas. São Paulo, SP: UBU.

Farah, Marta F. S. (2004). Gênero e políticas públicas. Revista Estudos Feministas, 12(1), 47-71. doi: 10.1590/S0104026X2004000100004

Fleury, Maria Teresa L. (2000). Gerenciando a diversidade cultural: Experiências de empresas brasileiras. RAE-Revista de Administração de Empresas, 40(3), 18-25. doi: 10.1590/ So034-75902000000300003

Gonzalez, Lélia. (1984) Racismo e sexismo na cultura brasileira. Revista Ciências Sociais Hoje, 223-244.

Gouvêa, Josiane B., \& Oliveira, Josiane S. de. (2020). Por que branquitudes, por que (somente) agora? Caderno de Administração, 28(2), 5-14. doi: 10.4025/cadm.v28i2.57245

Guzmán, Virginia. (2001). La institucionalidad de género en el estado: Nuevas perspectivas de análisis (Serie Mujer y Desarrollo, n. 32).. Santiago, Chile: Cepal.

Hanashiro, Darcy M. M., \& Carvalho, Sueli G. de. (2005). Diversidade cultural: Panorama atual e reflexões para a realidade brasileira. $R E A d, 11(5), 1-21$.
Hodges-Aeberhard, Jane. (1999). Affirmative action in employment: Recent court approaches to a difficult concept. International Labour Review, 138(3), 247-272. doi: 10.1111/j.1564-913X.1999.tboo387.X

Hooks, Bell. (2000). Feminism is for everybody. Cambridge, UK: South End Press.

Instituto Ethos. (2016). Perfil social, racial e de gênero das 500 maiores empresas do Brasil e suas ações afirmativas. Ethos.

Jaccoud, Luciana, \& Beghin, Nathalie. (2002). Desigualdades raciais no Brasil: Um balanço da intervenção governamental. IPEA. Brasília.

Jaime, Pedro. (2016). Executivos negros: Racismo e diversidade no mundo empresarial. São Paulo, SP: Edusp.

Lorde, Audre. (1984). Sister outsider: Essays and speeches. Berkeley, CA Crossing Press.

Lugones, María. (2014). Rumo a um feminismo descolonial. Revista Estudos Feministas, 22(3), 935-952. doi: 10.1590/ S0104-026X2014000300013

Marcondes, Mariana M. (2019). Transversalidade de gênero em políticas de cuidado: Uma análise comparada das políticas de cuidado infantil no Brasil, Argentina e Uruguai durante o giro à esquerda (Tese de doutorado, Escola de Administração de Empresas de São Paulo, Fundação Getulio Vargas, São Paulo, SP).

Marcondes, Mariana M., Sandim, Tatiana L., \& Diniz, Ana Paula R. (2018). Transversalidade e intersetorialidade: Mapeamento do debate conceitual no cenário brasileiro. Administração Pública e Gestão Social, 10(1), 22-33. doi: 10.21118/apgs. v10i1.1527

Moehlecke, Sabrina. (2002). Ação afirmativa: História e debates no Brasil. Cadernos de Pesquisa, 117, 197-217. doi: 10.1590/ S0100-15742002000300011

Munanga, Kabengele. (2015). Porque o racismo e suas práticas e qual é a responsabilidade social que se espera dos profissionais que lidam com as questões da sociedade. Revista Brasileira de Psicologia, 2 (núm. Esp.), 7-15.

Nascimento, Beatriz. (1990). A mulher negra e o amor. Jornal Maioria Falante, (17).

Paniza, Maurício D. R. (2020). Entre a emergência, a submersão e o silêncio: LGBT como categoria de pesquisa em administração. Cadernos EBAPE.BR, 18(1), 13-27. doi: 10.1590/1679-395173482

Papa, Fernanda de C. (2012). Transversalidade e políticas públicas para mulheres no Brasil: Percursos de uma prépolítica (Dissertação de mestrado, Escola de Administração de Empresas de São Paulo, Fundação Getulio Vargas, São Paulo, SP).

Pate, Kimberley. (2000). Ação afirmativa nos Estados Unidos. In D. G. Delgado, P. Cappelin, \& V. Soares (Eds.), Mulher e trabalho: Experiências de ação afirmativa (pp. 85-110). São Paulo, SP: Boitempo Editorial.

Peci, Alketa. (2006). A nova teoria institucional em estudos organizacionais: Uma abordagem crítica. Cadernos EBAPE.BR, 4(1), 1-12. doi: 10.1590/S1679-39512006000100006 
Piovesan, Flavia. (2008). Ações afirmativas no Brasil: Desafios e perspectivas. Revista de Estudos Feministas, 16(3), 887-896. doi: 10.1590/S0104-026X2008000300010

Prügl, Elisabeth. (2011). Diversity management and gender mainstreaming as technologies of government. Politics and Gender, 7(1), 71-89. doi: 10.1017/S1743923X10000565

Quijano, Anibal. (2005). Colonialidade do poder, eurocentrismo e América Latina. Buenos Aires, Argentina: Consejo Latinoamericano de Ciencias Sociales (CLACSO).

Ramos, Alberto G. (1981). A nova ciência das organizações: Uma reconceituação da riqueza das nações. Rio de Janeiro, RJ: FGV.

Reinach, Sophia. (2013). Gestão transversal de políticas públicas no âmbito federal brasileiro: Uma leitura inicial (Dissertação de mestrado, Escola de Administração de Empresas de São Paulo da Fundação Getulio Vargas, São Paulo, SP).

Rezende, Ana F., Mafra, Flávia L. N., \& Pereira, Jussara J. (2018). Black entrepreneurship and ethnic beauty salons: Possibilities for resistance in the social (re)construction of black identity. Organizações \& Sociedade, 25(87), 589-609. doi: 10.1590/1984-9250873

Said, Edward. (2007). Orientalismo: O Oriente como invenção do Ocidente. São Paulo, SP: Companhia das Letras.

Santos, Boaventura de S., Araújo, Sara, \& Baumgarten, Maíra. (2016). As epistemologias do Sul num mundo fora do mapa. Sociologias, 18(43), 14-23. doi: 10.1590/15174522-018004301

Santos, Georgina de C. M., Rodrigues, Ivete, Dutra, Shirley E., \& Costa, Bruna de V. L. da. (2008). Gestão da diversidade: Um estudo sobre as "melhores empresas para você trabalhar". Seminários de Administração, 11, 1-16.

Santos, Joel. R. D. dos. (1999). A inserção do negro e seus dilemas. Parcerias Estratégicas, 4(6), 110-154.
Santos, Neusa de S. (1983). Tornar-se negro: As vicissitudes da identidade do negro brasileiro em ascensão social. Rio de Janeiro, RJ: Edições Graal.

Saraiva, Luiz Alex S., \& Irigaray, Hélio Arthur dos R. (2009). Políticas de diversidade nas organizações: Uma questão de discurso? RAE-Revista de Administração de Empresas, 49(3), 337-348. doi: 10.1590/S0034-75902009000300008

Scott, Joan W. (2005). O enigma da igualdade. Revista de Estudos Feministas, 13(1), 11-30. doi: 10.1590/S0104 026X2005000100002

Semesp. (2020). Mapa do ensino superior no Brasil (10 ed.). São Paulo, SP: Semesp.

Silva, Rosana O., André, Robson G., Wanderley, Sérgio. E. P. V., \& Bauer, Ana P. M. (2020). Josué de Castro e a colonialidade do poder, do ser e do saber: Uma contribuição para a opção decolonial em estudos organizacionais. Sociedade, Contabilidade $e$ Gestão, 15(1), 41-60. doi: 10.21446/scg_ufrj.voio.21599

Teixeira, Juliana. (2020). Interseccionalidade. Observatórios das Desigualdades da Universidade Federal do Rio Grande do Norte (UFRN). Glossário das desigualdades. Retrieved from https://ccsa.ufrn.br/portal/?author=101050

Thomas, Roosevelt R. Jr. (1990). From affirmative action to affirmative diversity. Harvard Business Review, 68(2), 107-117. Retrieved from https://hbr.org/1990/03/from-affirmativeaction-to-affirming-diversity

Truth, Sojourner. (1851). E não sou mulher? Retrieved from https://www.geledes.org.br/e-nao-sou-uma-mulhersojourner-truth/

Walby, Sylvia. (2005). Gender mainstreaming: Productive tensions in theory and practice. Social Politics: International Studies in Gender, State \& Society, 12(3), 321-343. doi: $10.1093 / \mathrm{sp} / \mathrm{jxi} 018$

\section{AUTHOR'S CONTRIBUITIONS}

Ana Diniz, Josiane Silva de Oliveira, Juliana Cristina Teixeira and Mariana Mazzini Marcondes worked on the conceptualization and theoretical-methodological approach. The theoretical review was conducted by Ana Diniz, Josiane Silva de Oliveira, Juliana Cristina Teixeira and Mariana Mazzini Marcondes. Data collection was coordinated by Ana Diniz, Josiane Silva de Oliveira, Juliana Cristina Teixeira and Mariana Mazzini Marcondes. Data analysis included Ana Diniz, Josiane Silva de Oliveira, Juliana Cristina Teixeira and Mariana Mazzini Marcondes. All authors worked together in writing and revising the final draft of the manuscript. 